\title{
Field evaluation of an insect growth regulator, pyriproxyfen, against Culex pipiens pallens and Culex tritaeniorhynchus
}

\author{
Kiyoshi Kamimura* and Ryo Arakawa* \\ Laboratory of Parasitology, Toyama Medical and Pharmaceutical University, \\ Toyama 930-01, Japan
}

(Received: February 4, 1991)

Key words: insect growth regulator, pyriproxyfen, Culex pipiens pallens, Culex tritaeniorhynchus, mosquito control, Japan.

\begin{abstract}
A synthetic chemical, 0.5\% granules of pyriproxyfen (S-31183), which acts as a juvenile hormone, was tested against Culex pipiens pallens and Cx. tritaeniorhynchus under field conditions. This compound was extremely effective against larvae of both species which showed high resistance to organophosphorus insecticides. Complete inhibition of adult emergence continued for 3 weeks or more in open polyethylene containers and irrigation ditches at a dosage of $0.01 \mathrm{ppm}$, in cesspools at $0.05 \mathrm{ppm}$ and in sewers with inflow of house wastewater at $0.1 \mathrm{ppm}$ (AI). Activity of the compound was retained after a drying of the test site for several days. For evaluation of the effect of IGRs in the field, pupal isolates are preferable to larval isolates.
\end{abstract}

\section{INTRODUCTION}

By repeated applications of organophosphorus insecticides Culex pipiens pallens Coquillett and Cx. tritaeniorhynchus Giles, vectors of filariasis and Japanese encephalitis, respectively, became resistant to these insecticides and so their control is difficult now (e.g., Kamimura and Maruyama, 1983; Maruyama et al., 1984; Watanabe et al., 1990). Recently some insect growth regulators (IGRs) have been synthesized and they are expected to control these resistant mosquitoes (Mian and Mulla, 1982). Pyriproxyfen, one of these IGRs, shows an activity like a juvenile hormone (Syafruddin et al., 1990). This IGR exhibited a high level of activity against Culex, Aedes, Psorophora and Ano-

\footnotetext{
*上村 清, 荒川 良：富山医科薬科大学医学部寄生 虫学教室 (豆930-01 富山市杉谷 2630)
}

pheles mosquitoes (Mulla et al., 1986, 1989; Kawada et al., 1988; Schaefer et al., 1988; Suzuki et al., 1989; Kerdpibule, 1989; Mulligan et al., 1990; Ishii et al., 1990). However, none of those experiments emphasized the efficacy of pyriproxyfen against organophosphorus-resistant mosquitoes.

In the present study we evaluated pyriproxyfen against highly organophosphorusresistant mosquitoes, $C x$. pipiens pallens and $C x$. tritaeniorhynchus in the field.

\section{Materials and Methods}

The compound evaluated was granular formulation of $0.5 \%$ pyriproxyfen (S-31183) which was provided by Sumitomo Chemical Co., Ltd., Osaka, Japan.

The following experiments were carried out in the suburbs of Toyama City (Kamimura, 1991).

A) Polyethylene containers with Cx. pi- 
piens pallens. We placed 15 polyethylene containers $(40 \times 60 \mathrm{~cm}$ by $15 \mathrm{~cm}$ deep $)$ at an open site in the campus of Toyama Medical and Pharmaceutical University to allow $C x$. pipiens pallens to breed naturally (Fig. 1). After the appearance of mosquito larvae and pupae, 3-4 containers each were treated with pyriproxyfen at dosages of 0.1 , $0.01,0.001$ or $0.0001 \mathrm{ppm}$ (AI) on July 23, 1986. Two containers for control remained untreated.

B) Cesspools with $C x$. pipiens pallens. Two polluted waste-water cesspools $(8 \times 6 \mathrm{~m}$ by $0.1 \mathrm{~m}$ deep and $6 \times 7 \mathrm{~m}$ by $2.51 \mathrm{~m}$ deep) in an open site beside a pig shed where many $C x$. pipiens pallens inhabited were treated with pyriproxyfen at a dosage of $0.05 \mathrm{ppm}$ (AI) on July 28, 1986.

C) Sewers with Cx. pipiens pallens. Four open sewers $(10-30 \mathrm{~m}$ long, $0.3-0.5 \mathrm{~m}$ wide by $0.05-0.2 \mathrm{~m}$ deep) where many $C x$. pipiens pallens inhabited were treated with pyriproxyfen at a dosage of $0.1 \mathrm{ppm}$ (AI) on July 28 or August 4, 1986. In these sewers water was stagnant during the day, but inflow of house wastewater was observed every morning and evening.

D) Ditches with Cx. tritaeniorhynchus. A ditch $(300 \mathrm{~m}$ long, $4.7 \mathrm{~m}$ wide by $0.4 \mathrm{~m}$ deep) surrounding a farmhouse and 2 irrigation ditches $(2 \times 5 \mathrm{~m}$ by $0.12 \mathrm{~m}$ deep and $2 \times 10 \mathrm{~m}$ by $0.2 \mathrm{~m}$ deep) in agricultural land where many $C x$. tritaeniorhynchus inhabited were treated at a dosage of $0.01 \mathrm{ppm}$ (AI) on July 28 or August 4, 1986.

For evaluation of the compound, the pupal and larval isolate methods were utilized. Pupae were collected from the test sites one day before treatment and at intervals of 1-7 days after treatment till September 16, 1986 (Tables 1-3, Fig. 2). Duplicate samples of 25 pupae each were placed in a plastic cup filled with $100 \mathrm{ml}$ deionized water, and maintained in the laboratory at $25-27^{\circ} \mathrm{C}$ until all pupae died or emerged.

When pupae were not collected in sufficient number, 3 rd and 4th instar larvae were collected with field water. At site 5, 8 and 9 of Tables 2 and 3 few pupae were collected throughout the survey, so that only the larval isolate method was utilized. Twenty-five larvae each were placed in a cup with $100 \mathrm{ml}$ of field water, from where the larvae were

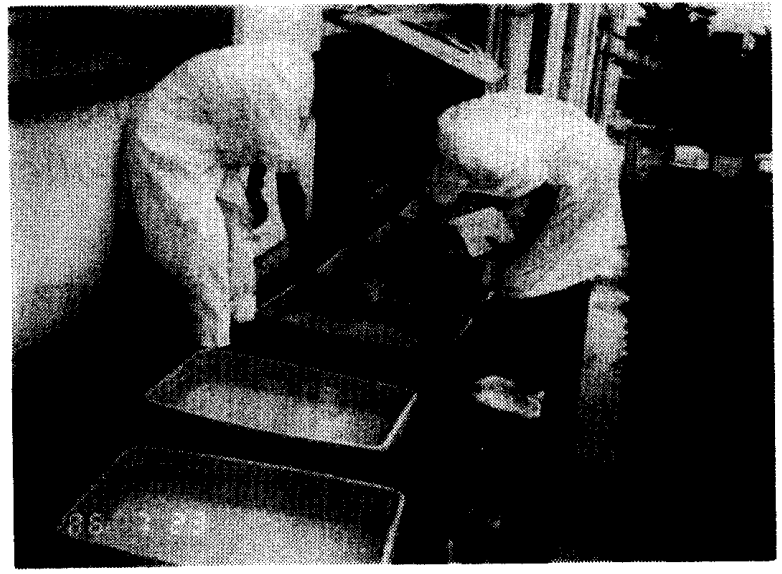

Fig. 1 Treatment of polyethylene containers in the campus with $0.5 \%$ pyriproxyfen granules.

collected. They were fed powdered baby food (dried liver and vegetables from Yukijirushi Co., Ltd.). The observation method after pupation was the same as that in the pupal isolates. Mortality readings were taken daily, and dead larvae, pupae and adults were counted and removed. Adults which underwent incomplete emergence and larvae which died before pupation were counted as inhibited.

\section{Results}

Water temperature in the test sites was $23-30^{\circ} \mathrm{C}$ and average air temperature was $21.0-29.9^{\circ} \mathrm{C}$ (mean $25.5^{\circ} \mathrm{C}$ ) during the test period. It rained on August 4, 5, 6, 7, 22, 23 and 24 and September 3, 9 and 10 (Fig. 2). Total precipitation was $185 \mathrm{~mm}$. In pupae from the control site and pretreatment samples from the test sites, mortality in the laboratory was observed at $0-4.5 \%$ (mean $1.5 \%$; Tables $1-3$ ).

\section{A) Polyethylene containers with Cx. pipiens pallens}

Adult emergence was completely inhibited for 40 days after treatment at a high dosage, $0.1 \mathrm{ppm}$. All larvae died before pupation in the containers treated at $0.1 \mathrm{ppm}$ for 25 days after treatment. Sufficient number of pupae for evaluation first appeared 27 days after treatment. Due to depression of pupal population, further observation was not continued after then (Table 1, Fig. 2). 


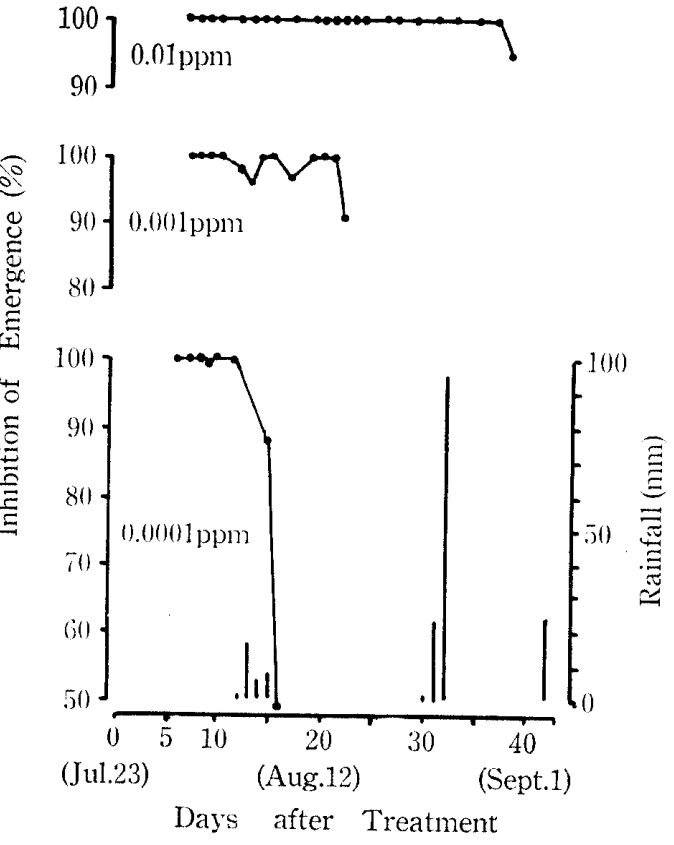

Fig. 2 Residual activities of $0.5 \%$ pyriproxyfen granules against Culex pipiens pallens in polyethylene containers and rainfall in Toyama.

Emergence was almost inhibited for 38 days and 22 days after treatment at 0.01 and $0.001 \mathrm{ppm}$, respectively, in spite of several days' rainfall.

Inhibition was almost complete for 12 days after treatment at a low dosage of 0.0001 $\mathrm{ppm}$, but the rate decreased rapidly after rainfall during 13th-19th day after treatment.

\section{B) Cesspools with Cx. pipiens pallens}

Complete inhibition of adult emergence was produced during $4-43$ days after treatment in the pupal isolates (Table 2).

Nearly half of inhibition for the first 2 weeks in larval isolates was larval death. Nevertheless, the inhibition rate was lower in the larval isolates than in pupal isolates. Some adults emerged normally 1 week after treatment in the larval isolates. After that, the rate of normal emergence was reduced to $0-2 \%$, but the rate gradually increased within 36-50 days after treatment.

One cesspool (Site No. 2 of Table 2) dried up for 4 days from 22nd to 25th day after treatment, and then the water level recovered with rainfall. Third and 4th instar larvae appeared again 36 days after treatment, but the inhibition rate stayed at the $74-85 \%$
Table 1 Residual activity of $0.5 \%$ pyriproxyfen granules as measured by inhibition of adult emergence against $C x$. pipiens pallens in polyethylene containers.

\begin{tabular}{|c|c|c|}
\hline $\begin{array}{l}\text { Dose } \\
\text { (ppm) }\end{array}$ & $\begin{array}{l}\text { Days after } \\
\text { treatment }\end{array}$ & $\begin{array}{l}\text { Inhibition rate } \\
\text { of emergence } \\
\text { (No. samples) }\end{array}$ \\
\hline 0.1 & $27-40$ & $100 \quad(190)$ \\
\hline \multirow[t]{2}{*}{0.01} & $7-37$ & $100 \quad(2,024)$ \\
\hline & 38 & $94.9 \quad(39)$ \\
\hline \multirow[t]{7}{*}{0.001} & $7-10$ & $100 \quad(1,758)$ \\
\hline & 12 & $97.7 \quad(173)$ \\
\hline & 13 & $96.1 \quad(51)$ \\
\hline & $14-15$ & $(9)$ \\
\hline & 17 & $97.3 \quad(73)$ \\
\hline & $19-21$ & $100 \quad(175)$ \\
\hline & 22 & $91.0 \quad(100)$ \\
\hline \multirow[t]{6}{*}{0.0001} & $6-8$ & $(641)$ \\
\hline & 9 & $99.5 \quad(201)$ \\
\hline & $10-12$ & $(160)$ \\
\hline & 13 & 87.5 \\
\hline & 17 & $11.0 \quad(127)$ \\
\hline & 19 & $31.5 \quad(124)$ \\
\hline \multirow[t]{4}{*}{0 (control) } & $6-17$ & $(163)$ \\
\hline & 19 & $0.5 \quad(218)$ \\
\hline & $20-31$ & $0 \quad(253)$ \\
\hline & $33-38$ & $0.6 \quad(172)$ \\
\hline
\end{tabular}

level during the period from 36 to 56 days after treatment.

C) Sewers with $C x$. pipiens pallens

Complete inhibition was produced during 4-22 days after treatment in the pupal isolates. The inhibition rate in the larval isolates was over $80 \%$ within 22 days after treatment and then it decreased gradually (Table 2).

\section{D) Irrigation ditches with Cx. tritaenio- rhynchus}

The inhibition rate in the pupal isolates was more than $98 \%$ during the period 4 to 22 days after treatment. The inhibition rate in the pupal isolates was $43-59 \%$ for the first 2 days after treatment. The same tendency was observed in the larval isolates. The rate rapidly dropped after rainfall on the 


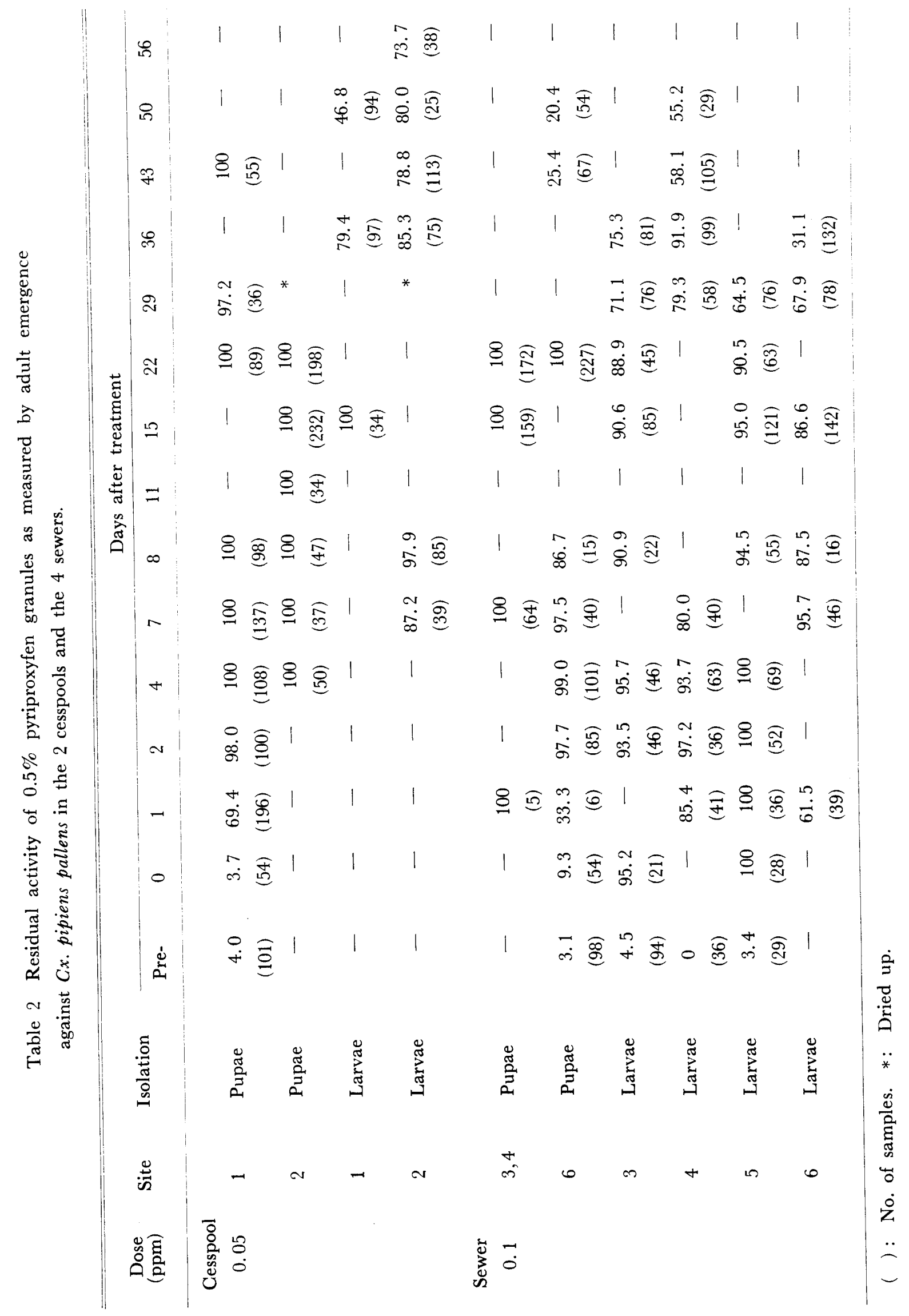


Table 3 Residual activity of $0.5 \%$ pyriproxyfen granules as measured by adult emergence against $C x$. tritaeniorhynchus in the 3 ditches.

\begin{tabular}{cccccccccccccc}
$\begin{array}{c}\text { Dose } \\
(\mathrm{ppm})\end{array}$ & Site & Inhibition & \multicolumn{10}{c}{ Days after treatment } \\
\cline { 3 - 13 } & & Pre- & 0 & 1 & 2 & 4 & 7 & 15 & 22 & 29 & 36 & 43 \\
\hline 0.01 & 7 & Pupae & 0 & 42.9 & 59.0 & 86.7 & 100 & 100 & 98.2 & 100 & - & - & - \\
& & & $(86)$ & $(21)$ & $(78)$ & $(150)$ & $(91)$ & $(157)$ & $(109)$ & $(5)$ & - & - & - \\
& 7 & Larvae & 1.8 & 100 & - & - & - & - & - & - & 74.4 & 52.0 & 32.0 \\
& & $(55)$ & $(23)$ & & & & & & & $(82)$ & $(75)$ & $(25)$ \\
& \multirow{2}{*}{8} & Larvae & 2.1 & 2.0 & 95.7 & 97.5 & 97.2 & 97.3 & 73.9 & 92.9 & 83.3 & 37.8 & 40.7 \\
& & $(48)$ & $(50)$ & $(47)$ & $(40)$ & $(36)$ & $(37)$ & $(92)$ & $(85)$ & $(60)$ & $(111)$ & $(113)$ \\
& \multirow{2}{*}{9} & Larvae & -- & 100 & 100 & 100 & 100 & 97.8 & $*$ & 92.0 & 21.1 & 16.2 & - \\
& & & $(2.5)$ & $(29)$ & $(26)$ & $(49)$ & $(45)$ & & $(25)$ & $(104)$ & $(74)$ &
\end{tabular}

( ) : No. samples. * Dried up.

29th day after treatment, both in pupal and larval isolates (Table 3 ).

One irrigation ditch (Site No. 9 of Table 3 ) dried up for 4 days, August 15-18, and then the water level recovered with rainfall. The inhibition rate in larval isolates after the dry-up was still $92 \% 22$ days after treatment, but the rate decreased rapidly after rainfall during 29-36 days after treatment.

\section{Discussion}

Pyriproxyfen effectively inhibited adult emergence of $C x$. pipiens pallens and $C x$. tritaeniorhynchus for more than 3 weeks in ditches with wastewater inflow at a dosage of $0.1 \mathrm{ppm}$ and in those with stagnant wastewater of $0.01 \mathrm{ppm}$. This IGR produced complete inhibition of emergence of $C x$. pipiens pallens for rainless 12 days in the polyethylene containers without mud on the bottom at a very low dosage of $0.0001 \mathrm{ppm}$, but the effect decreased rapidly when the concentration was diluted by rain water (Fig. 2).

The high effect of granular formulation was retained in the cesspools and irrigating ditches after drying up for several days in the course of the experiments.

However, the effective component did not remain in the bottom mud for a long period when an emulsion was sprayed (Schaefer et al., 1988). We thought that granules of this IGR sank to the bottom, and the effective component was slowly released; thus, the effective component remained in the substratum for a long time.

It is already confirmed that emergence inhibition rates were higher in pupal isolates than in larval isolates (Mulligan and Schaefer, 1990). The same results were obtained in the present study. Concentration was expected to be higher in the bottom than the upper water for a long time when granular formulation was applied. This IGR is active against the larval stage, and inactive against pupae (Hatakoshi et al., 1987). The age sensitivity of larvae differs in instars (Estrada and Mulla, 1986). Through eating bottom mud and/or floating fine particles containing the active component, larval midguts and Malpighian tubes are destroyed (Syafruddin et al., 1990). Therefore, field-collected pupae might contact higher concentration on the bottom through touch and/or eating mud at their larval stage. In the larval isolate only the field-collected water was used, so larvae could not contact the bottom mud at the stage they were sensitive to the chemical. To determine the effect of IGRs in the field, pupal isolates are stable and are preferable to larval isolates. In the plots treated at high dosage of $0.05-0.1 \mathrm{ppm}$, many larvae died and pupal populations were depressed, and so the actual mortality in the test sites at high dosages is expected to be higher than that obtained in the pupal isolates.

\section{Acknowledgements}

This study was supported by JS Research So- 
ciety, Japan Environmental Sanitation Center. We are deeply indebted to I. Tanaka, G. Shinjo, T. Okazawa, Syafruddin and the members of the JS Research Society for their helpful suggestions.

\section{RefERENCES}

Estrada, J. G. and M. S. Mulla (1986): Evaluation of two new insect growth regulators against mosquitoes in the laboratory. J. Am. Mosq. Control Assoc., 2: 57-60.

Hatakoshi, M., H. Kawada, S. Nishida, H. Kisida and I. Nakayama (1987): Laboratory evaluation of 2-\{1-methyl-2-(4-phenoxyphenoxy)-ethoxy\} pyridine against larvae of mosquitoes and housefly. Jpn. J. Sanit. Zool., 38: 271-274.

Ishii, T., Y. Utsumi, A. Kamada and M. Kamei (1990): Field trials of BCP-8702 against mosquito larvae in ditches. J. Sci. Univ. Tokushima, 23: 9-19 (in Japanese with English summary).

Kamimura, K. (1991): Field evaluation of an insect growth regulator, pyriproxyfen, against the housefly, Musca domestica. Jpn. J. Environ. Entomol. Zool., 3: 1-6.

Kamimura, K. and Y. Maruyama (1983): Appearance of highly resistant strain of Culex tritaeniorhynchus to organophosphorus insecticides. Jpn. J. Sanit. Zool., 34: 33-37 (in Japanese with English summary).

Kawada, H., K. Dohara and G. Shinjo (1988) : Laboratory and field evaluation of an insect growth regulator, 4-phenoxyphenyl (RS)-2-(2pyridyloxy) propyl ether, as a mosquito larvicide. Jpn. J. Sanit. Zool., 39: 339-346.

Kerdpibule, V. (1989): A field test of 2-[1methyl-2-(4-phenoxyphenoxy)ethoxy] pyridine against principal vectors of malaria in a foot-hill area in Thailand. Jpn. J. Trop. Med. Hyg., 17: 175-183.

Maruyama, Y., K. Yasutomi and Z. Ogita (1984) : Electrophoretic analysis of esterase isozymes in organophosphate-resistant mosquitoes (Culex pipiens). J. Insect. Biochem., 14: 181-188.

Mian, L. S. and M. S. Mulla (1982): Biological and environmental dynamics of insect growth regulators (IGRs) as used against Diptera of public health importance. Residue Rev., 84: 27-112.

Mulla, M. S., H. A. Darwazeh, B. Kennedy and D. M. Dawson (1986): Evaluation of new insect growth regulators against mosquitoes with notes on nontarget organisms. J. Am. Mosq. Control Assoc., 2: 314-320.
Mulla, M. S., H. A. Darwazeh and E. T. Schreiber (1989): Impact of new insect growth regulators and their formulations on mosquito larval development in impoundment and floodwater habitats. J. Am. Mosq. Control Assoc., 5: 1520.

Mulligan III, F. S. and C. H. Schaefer (1990): Efficacy of a juvenile hormone mimic, pyriproxyfen (S-31183), for mosquito control in dairy wastewater lagoons. J. Am. Mosq. Control Assoc., 6: 89-92.

Schaefer, C. H., T. Miura, E. F. Dupras, Jr., F. Mulligan III and W. H. Wilder (1988): Efficacy, nontarget effects, and chemical persistence of S-31183, a promising mosquito (Diptera: Culicidae) control agent. J. Econ. Entomol., 81: 1648-1655.

Suzuki, H., T. Okazawa, N. Kere and H. Kawada (1989): Field evaluation of a new insect growth regulator, pyriproxyfen, against Anopheles farauti, the main vector of malaria in the Solomon Islands. Jpn. J. Sanit. Zool., 40: 253 257.

Syafruddin, R. Arakawa, K. Kamimura and F. Kawamoto (1990): Histopathological effects of an insect growth regulator, 4-phenoxyphenyl $(R S)$-2-(2-pyridyloxy) propyl ether (pyriproxyfen), on the larvae of Aedes aegypti. Jpn. J. Sanit. Zool., 41: 15-22.

Watanabe, M., R. Arakawa and K. Kamimura (1990): Relationship between yearly change of captured numbers and insecticide resistance of Culex tritaeniorhynchus in Toyama Prefecture. Jpn. J. Sanit. Zool., 41: 51-58 (in Japanese with English summary).

$$
\begin{gathered}
\text { 摘 要 } \\
\text { アカイエカ, コガタイエカに対する昆虫 } \\
\text { 成長制御剂ピリプロキシフェンの } \\
\text { 野外効力試験 }
\end{gathered}
$$

幼若ホルモン様活性を示すピリプロキシフェン（S31183） $0.5 \%$ 粒剂の，有機燐剂抵抗性を呈すアカイエ カ，コガタイエカに対する野外効力試験を行った．そ の結果, 開放的なポリ容器と排水溝では, $0.01 \mathrm{ppm}$, 停滞した污水槽では $0.05 \mathrm{ppm}$ ，流れのある下水溝で は $0.1 \mathrm{ppm}$ の散布で， 3 週間以上ほぼ完全に羽化を 阻害した. 発生源が一時的に干上がっても, その後む 効力が持続した。採集蛹での羽化阻害成績は, 実際の 死亡率を過少評価しやすいが，安定していて，幼虫と 発生源の水を用いた成績よりもすぐれている。 